\title{
Trust as One of the Fundamental of Innovation and Human Governance to Enhance Productivity and Economic Growth
}

\author{
Dr. Aini Suzana Hj Ariffin \\ Dr. Shadiya Mohamed Baqutayan
}

Perdana School of Science, Technology \& Innovation Policy, University Technology Malaysia

\section{Doi:10.5901/mjss.2015.v6n3s2p318}

\begin{abstract}
The words trust "Amanah" and Governance are not new terms to all of us, it's often in modern society's dialogues and always been mentioned in media and everywhere. But how much do we understand these words are another issue. Deeply understand the words "Amanah" and Governance is crucial. Once we understand these two magic words, it may help us to apply and adopt the human governance and innovation concepts effectively in our daily tasks that we were assigned for. The purpose of this study is twofold: to understand the exact meaning of "Amanah", and to provide suitable model that brings trust "Amanah" and Governance into one. In attempting to this debate the emphasis is more on the literature that focuses on the meaning of trust "Amanah" and Governance. The word "Amanah" in this paper means to be in the state of peace, safety and security. On the other hand trust is defines as man's rights and responsibilities in relation to all other humans, environment, society and the rest of God's creation. This paper will briefly focus on trust and human's responsibilities towards corporate governance and innovation in order to enhance the economic growth and quality of life of human being as well as the nation.
\end{abstract}

Keywords: Trust, Innovation, Human Governance, Productivity, Economic Growth

\section{Introduction}

First of all, before I elaborate further on the above topic, let us deeply understand the words "Amanah" and Governance. Once we understand these two magic words, it may help us to apply and adopt the human governance and innovation concepts effectively in our daily tasks that we were assigned for. The word "Amanah" originates from three-letters rootverb A, M and N (amn), which means to be in the state of peace, safety and security. In the noun form, the word becomes (aman), meaning peace, security, safety, shelter and protection. "Amanah" literally means trust, reliability, trustworthiness, loyalty, faithfulness, integrity, honesty and confidence. In the Holy Qur'an it stated that "Amanah" (trust) is given to mankind and basically is a contract between God and man. A trust is which the heavens, the earth, and mountains refused to accept, because they were afraid of its heavy burden (33: 72); which requires the establishment of justice in society (4: 58). In other word, it defines man's rights and responsibilities in relation to all other humans, environment, society and the rest of God's creation (Zein et al, 2008). This paper will briefly focus on trust and human's responsibilities towards corporate governance and innovation in order to enhance the economic growth and quality of life of human being as well as the nation.

\section{Literature Review}

What is trust? In simple word trust means confidence. When I trust someone I can feel it. I have confidence in his or her integrity and abilities. However, when I distrust someone, I am always suspicious his or her integrity, agenda and capabilities. Trust truly is the one thing that changes everything. As quoted by Mahatma Gandhi "the moment there is suspicion about a person's motives, everything he does becomes tainted" (Meier, 2015). In addition nothing is as profitable as the economics of trust and nothing has more influence than a reputation of trust. Let us takes a few examples of frustration and discouragement such as; "My boss micro manages me and manages everyone at work. He treats us all like we cannot be trusted". "I work in an organization that bogged down with bureaucracy, it takes forever to get anything done, I have to get authorization even to buy a pen". "I feel like my contributions at work are hardly ever recognized or valued?" "I have really been burned in the past, how can I ever trust anyone to have a real relationship?" "I am not allowed to be opened; if I say what I really think, I will get fired or at least made irrelevant".

It's noticeable that where a lack of trust may create politics and bureaucracy and slows things down. Do we accept 
this as the cost of doing business? In business dealing, trust always affects two outcomes; speed and cost. When trust decrease, speed will reduce and costs will increase. For example, following the 9/11 terrorist attacks, trust in flying went down dramatically. Prior to $9 / 11$ incidents, I used to arrive at the airport one hour before departure, and I was able to go through security. However, after 9/11 more robust procedures were in placed to increase safety and trust in flying. I need to arrive two or three hours before an international flight to make sure I have enough time to clear security. Now it takes me longer and costs me more to travel. So as trust decreased, speed went down and cost increased.

In another situation where our distrust is very expensive, recently, missing of MH 370 in April 2014 and MH 17 terrorist attacked on 17th July 2014, trust in flying Malaysia Airlines went down dramatically. The number of tourist visiting Malaysia also decrease; and this cause a big lost to our hotel and tourism industry as well as to the country. Currently the company has to spent huge money on promotion and advertisement to regain the trust in flying with MAS Airlines. Many may agree that we cannot have success without trust. Science and technology are important, but adding trust is the issues of decade. The word trust embodies almost everything and there is no human relationship that works without trust. Whether it is a friendship, social interaction or a marriage, all need to be based on trust. The same thing is true about business and corporate world, especially businesses that deal with the public. And the Holy Quran verse 2: 283 emphasizes on the importance of trust in business transactions. Thus, we can do something about trust. In fact through innovation and innovative governance, one can establish, grow, extend, rebuild and restore trust and significantly alter the trajectory of this and every future moment in our life.

What are innovation and innovative governance? These two words are quite complex, yet universal force that exists in all societies. Firstly what is innovation? Innovation is the key driver for productivity, quality, economic growth, competitiveness and internationalization (Frontier Economics Ltd, 2013), and it has become a demanding and persistent issue in the academic literature, in policy development, in the business community as well as in society (Dosi, 1988; Nelson, 1993; Patel, 1995; Lundvall, 1998). Since innovation is the key driver for productivity and economic growth, it is important that everyone involved in the process of knowledge and technology development has the same understanding of innovation and its approach. This will benefit organizations because everyone will move towards achieving the organization's goals and national aspirations. Moreover, all innovation plans, initiatives and programs could be executed in a timely manner and effectively.

The word 'innovation' originates from Latin where 'nova' means new; as an introduction to new things or methods. The classic definitions of innovation derived from various sources; it includes the act of introduction, a new idea, method or device, changes that create a new dimension of performance and the process of making improvements by introducing something new (Ariffin, 2013). In addition, innovation has been defined in many different ways, subject to its applications, such as in the field of economic, social development, research and technology and lately in services. For example, in economic terms, any innovation must increase producer and customer value, as well as increase productivity, living standards and economy growth. In a corporate context, it includes organizational innovation, process innovation, product innovation, services innovation, business model innovation, market driven innovation as well as financial innovation.

I would like to share some of the definition of innovation introduced by various Gurus of innovation. Drucker (1985) elaborated that, from the business management point of view, there are only two main tasks: marketing and innovation. While the marketing function is to satisfy customers' current needs, innovation looks further in satisfying customers' future needs. Innovation is neither research nor science and technology. Porter (1985) defines innovation as both: improvements in a technology and better methods and ways doing things. These include product changes, process changes, new approaches to marketing, new forms of distribution and new conceptions of scope. Milbergs \& Vonortas (2004) states that innovation is a process through which the nation creates and transforms new knowledge into useful products, services and processes for national and global markets, leading to both value creations for the stakeholder and higher standards of living. The majority of these definitions focus on new products and new methods of production. The argument for focusing on these two is often based on their economic and social impact. The introduction of new products is commonly assumed to have a clear, positive effect on growth of income and employment.

In the 21st century, innovation is much more about literally understanding the problem better, the political issue, the societal issue, the business issue, the academic issue; so that you can then take your technical knowledge and apply it in new and uniquely different ways. Sometimes it's just seeing things that other people missed. It's looking at these deep intersections or interstices and seeing something that nobody else saw before, and that becomes the innovation. It's the ability to generate new economic wealth where it couldn't have been generated before. I of the same view define innovation as: a process of conversion of an idea into a saleable, new or improved product or into a new or improved process used in the production of goods and services. In addition innovation must translate into something new and different, with an added value and it is also a change that is able to bring about an improvement in life, be it in the product or process that it develops, the way it works, or the way it delivers value to stakeholders and services to customers. 
Nowadays, the pace of market and technology changes in all economies and societies is very fast. Countries, industries, companies, research organizations, universities, science parks, incubation centres, or even individuals that are less innovative, particularly those dealing in knowledge-based and technology development businesses, find it more difficult to survive or sustain their business venture. Many business experts and academicians, such as Porter (1985), Drucker (1985), and Freeman (1987), have all stressed the importance of innovation and innovative governance have claimed that without the ability for constant innovation, or failing to match technology, market and customer requirements, the country's industry may be ruined, research universities and institutes may become irrelevant, companies may be out of business and individuals may be made redundant and unemployed.

Innovative governance has become a key subject of study in science and technology, R\&D, economics, marketing, finance and human resource management. Roles and challenges in delivering technological innovation have been widely studied, but the focus has been mainly on universities and only limited focus has been paid to public research and technology organizations including research universities (RUs). The RUs have faced significant changes due to additional accountability directive from shareholders. To explain this assertion, traditionally, the main task of the RUs was research and technology development to assist public good and local industry sectors. However, due to globalization and the huge amount of competition that has resulted from it, RUs are now required to generate revenue from the investment by their shareholders mainly for subsidiary companies.

Now, let us understand what is innovative governance and it roles in enhancing the technological innovation, productivity and economic growth of the organization. Many people use governance in their daily lives to manage human relationships and corporations use it to manage their interaction and activities (Cheema, \& Maguire, 2002). It is also refers to the degree to which the private sector and organizations of civil society are free and able to participate (Cheema, \& Maguire, 2002). Good governance exists when the authority of the top management is based on the will of the people and is responsive to them. In practice governance involves promoting the rule of law, tolerance of minority, transparent political process, fair judgment and treatment, an independent judiciary, a military that is strictly subject to civilian control etc.

Above all, good governance means respect for human rights (Cheema, \& Maguire, 2002). Yet even as good governance takes hold, challenges to it also emerge. The greatest threats to good governance today come from corruption, violence and poverty, all of which undermine transparency, security, participation and fundamental freedoms. How to deal with these challenges and is there any appropriate way that can be adopted to overcome these challenges? Ever one will be agreed, we need to be creative and innovate in order to solve issues or problems face. I for 25 years was as a strategies and business practitioner. I have been responsible for developing strategic innovation plan, implementing various policies and operation management systems, developing team, reporting to the top management and getting results as per the approved planned. I am confident I can make change on innovation governance initiatives any organization particularly for new business entity. The innovation governance scope and responsibilities covers the accountability and commitment on innovation; making decisions that define expectation and innovation budgets; defining how to measure innovation; prioritizing innovations activities across divisions and establishing management routines regarding communications and decisions. Below Table highlighted these scope and responsibilities:

Table 1: Innovation Governance Scope And Responsibilities

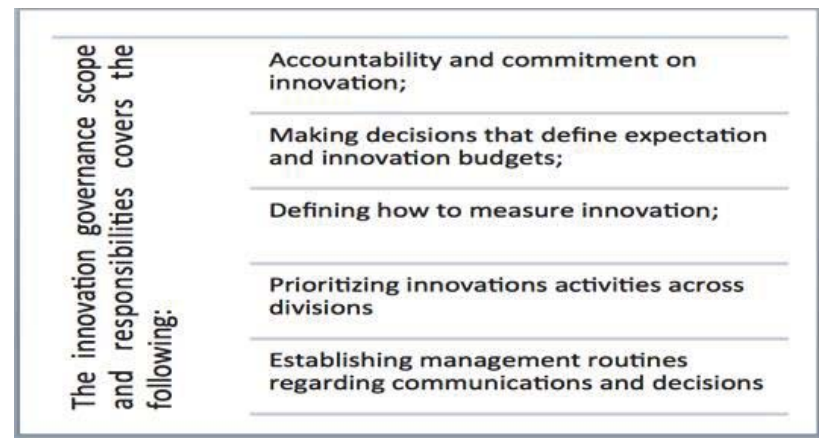

Innovation governance usually commences with top management commitment to promote various types of innovation in the organization where it encourages all employees to grab opportunities for innovation in all aspects. There are four functions of management to promote all types of innovations namely: 
- Building a vision, innovation trusts and strategy for innovation

- Discovering business opportunities and creation

- Developing capabilities include human governance capability

- Steering execution which include portfolios and commercialization

Table 1: Functions of management to promote innovations

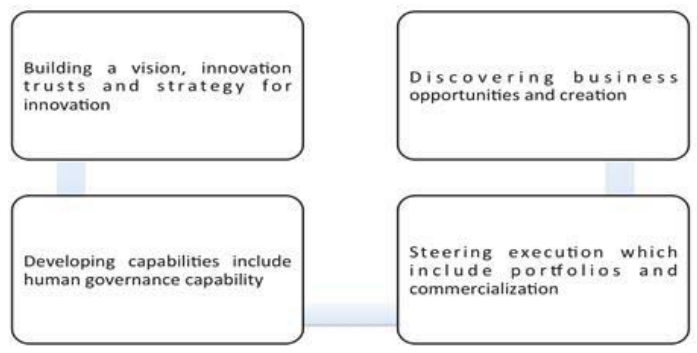

Briefly as part of this first innovation governance element, management to address three fundamental questions:

- Why innovate? What benefit can the company expect from innovation? What penalties might be incur if fail to innovate?

- Where to innovate? Which areas to focus innovation effort to implement innovation strategy?

- How much to innovate? How much risk can we tolerate in innovation drive and how many resources are ready to commit and contribute effectively.

Secondly the innovation governance element is focusing on discovering opportunities for innovation. In this context the foresight capability is very critical. Which mean the ability to track weak signals, sense emerging trends in the market, collection of critical data such market, customer, competitive and technological intelligence. It also requires a company positive attitude towards openness and curiosity. Many organizations have appointed a number of technology gatekeepers to follow the trend and progress of new technologies.

In innovation governance, two critical execution activities need major attention namely optimizing the project pipeline and steering the execution for innovation project by multi discipline team and designing and implementing phase processes. Managing members to address on: how to innovate more effectively? What approaches to be adopted to meet innovation objectives? Whom to innovate with? Who should be responsible? Who should be the owner of the new innovation efforts and what organizational business model to be adopted to steer innovations?

Lastly, innovation requires a range of hard skills such as new technological competencies and advanced commercial proficiency. Innovation governance also promotes enhancing value and behavior. Normally the range of values that companies promote includes:

$\checkmark$ Customer intimacy

$\checkmark$ Openness (open innovation where ideas derives from all over)

$\checkmark$ Risk taking, tolerance of failure and leaning from failures

$\checkmark$ Teamwork and collaborations across local and international

$\checkmark$ Entrepreneurship

$\checkmark$ Speed and sense of urgency

$\checkmark$ Expert in Project Management and budget control

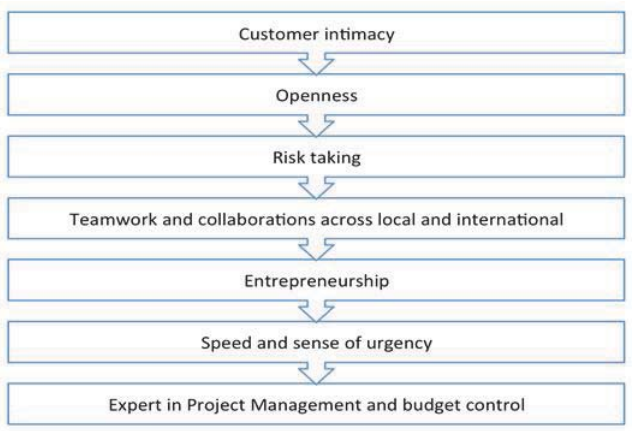

Figure 1: The value that governance promotes 


\section{Conclusion}

I would like to conclude that governing innovation means making sure that innovation strategy can be implemented smoothly and effectively to meet it objectives. Top management to build the trust culture, introduce and promote innovation and innovative governance as well as to take full responsibility for making sure that the design and organization are optimized so that all innovators in the organization have a chance to produce the value they are capable of delivering. Few things can help an individual more than to place responsibility on him, and to let him know that you trust him. This move may help to enhance the productivity of the organization and economic growth of the country. As emphasized by many experts, an innovation is not an innovation until someone has successfully implemented it and gained value from the idea generated. A discovery that moves from laboratory scale into production and adds economic value to the organization is considered an innovation. As conclusion innovations must have direct and positive impact on productivity, knowledge, wealth creation, economic growth of the country as well as well- being of the nation.

\section{Acknowledgement}

I would like to acknowledge and extend my heartfelt gratitude to The Ministry of Education and Universiti Teknologi Malaysia for the financial assistance in funding this research. My sincere thank to all my colleagues who kindly provided valuable and helpful comments of this paper.

\section{References}

Ariffin A.S (2013). Policy Transformation from Public Sector Agency to Business Entity: Lessons Learnt in Implementing Corporatization Policy by Government Linked Research \& Technology Organizations in Malaysia. Proceedings Book of ICEFMO, 2013, Malaysia Handbook on the Economic, Finance and Management Outlooks, PAK Publishing group.

Cheema G. S., and Maguire L., (2002). "Democracy, Governance and Development: A Conceptual Framework"; Background Paper of the 4th. Global Forum on Re-inventing Government, Marrakech, Morocco, 10 $-13^{\text {th }}$ December 2002, UN, New York 2002.

Dosi, G. (1988) The Nature of the Innovative Process, In: Dosi, G., Freemen, C., Nelson, R., Silverberg, G. and Soete, L. eds., Technical Change and Economic Theory, Printer Publishers, UK.

Drucker, Peter F., (1985) Innovation and Entrepreneurship: Practices and Principles, New York: Harper \& Row, Publishers, 220-225.

Freeman, C. (1987) Technology Policy and Economic Performance: Lessons from Japan, London, Printer.

Frontier Economics Ltd., (2013). Exploring the impact of private equity on economic growth in Europe. A report prepared for the EVCA. Retrieved, $4^{\text {th }}$ February, 2015, from: https://www.evca.eu/media/12929/Frontier-Economics-Report.pdf

Lundvall B. (1988). Innovation as an interactive process: from user-producer interaction to the national system of innovation. In G Dosi, C Freeman, R Nelson, G Silverberg, L Soete (Eds.), Technical Change and Economic Theory: pp.349-369. Pinter: London.

Meier, J.D., (2015). Gandhi Quotes. Retrieved, 3rd February, 2015, from: http://sourcesofinsight.com/gandhi-quotes/

Milbergs, E., \& Vonortas, N., (2004). Innovation Metrics: Measure- ment to Insight. National Innovation Initiative $21^{\circ}$ Century Innovation Working Group Chair, Nicholas M. Donofrio, IBM Corporation.

Nelson, R.R and Rosenberg, N. (1993) Technical Innovation and National System, National Innovation Systems: A Comparative Analysis, New York, Oxford University Press.

Patel, P. and Pavitt, K. (1994) The Nature and Economic Importance of National Innovation System, STI Review, OECD, Paris.

Porter, M. (1985) The Value Chain and Competitive Advantage: Creating and Sustaining Superior Performance, Free Press, New York.

Zein, I. M., et al (2008). Qur'anic Guidance on Good Governance. Center for Strategic and International Studies (CSIS), D.C. Washington. 